ARTIKEL PENELITIAN

\title{
OPINI MASYARAKAT TENTANG MALPRAKTEK KEDOKTERAN
}

\author{
Hardisman \\ Bagian Anestesiologi, \\ Bagian Pendidikan Kedokteran,Fakultas Kedokteran Universitas Andalas \\ email : hardisman@fk.unand.ac.id
}

\begin{abstract}
Abstrak
Dalam menjalankan profesinya, dokter harus taat pada norma-norma sosial, etika profesi dan hukum. Pelanggaran akan nilai-nilai tersebut dapat menjadi sorotan masyarakat, dan bisa berlanjut kepada tuduhan malpraktek kedokteran. Penelitian ini dilakukan untuk menilai bagaimana opini masyarakat tentang malpraktek kedokteran yang dianalisis berdasarkan prinsip-prinsip etika kedokteran. Untuk menjawab tujuan penelitian ini telah dilakukan online survei deskriptif dan kualitatif pada Bulan November 2009-Oktober 2010, dengan menggunakan kuisioner terstruktur dan pertanyaan terbuka. Respoonden didapatkan dengan teknik sampling non-probabilitas convenience sampling. Data dianalisa menggunakan prinsip-prinsip etika kedokteran secara deskriptif. Data kualitatif juga dilakukan analisa tematik serta ditampilkan dalam bentuk narasi. Secara umum opini masyarakat tentang malpraktek kedokteran sesuai dengan pandangan prinsip-prinsip etika kedokteran. Masyarakat berpendapat bahwa terjadinya malpraktek ada unsur kesalahan prosedur atau diagnosis dan penatalaksanaan. Namun, mereka cendrung pada filosofis konsekuentialis yang lebih menitik beratkan kepada akibat yang dialami oleh pasien yang kurang mempertimbangkan apa yang telah dilakukan dokter berdasarkan standar medis. Bahkan, ungkapan responden yang dianggapnya sebagai malpraktek lebih disebabkan karena ketidakpuasannya terhadap pelayanan yang diberikan. Ketidakpuasan tersebut timbul akibat rendahnya kualitas informasi dan sikap komunikasi dokter dan petugas dalam melakukan pelayanan. Oleh karena itu, untuk memperbaiki opini masyarakat dan mencegah berbagai tuduhan malpraktek, dokter dan petugas kesehatan harus mentaati etika dan standar profesi dalam melakukan pelayanan, serta memberikan informasi yang cukup dan komunikasi yang baik dengan pasien.
\end{abstract}

Kata Kunci: Malpraktek kedokteran, etika, dan opini masyarakat.

\section{Abstract}

In providing services, medical professionals have to aware on social norms, ethics and laws. The behaviours which against those regulations attract public attention and can lead to medical malpractice allegations. This research was conducted to explore public opinion on medical malpractice, which was analyzed base on medical ethic principles. To answer the research question, descriptive and qualitative online survey has been conducted from November 
2009 to October 2010, which used structured and open ended questionnaire. The participants were selected by employing non-probability convenience sampling. Later, the quantitative data was analyzed descriptively, and the qualitative data was also analyzed thematically and presented narratively. In general, public opinion on malpractice is similar to the principles of medical ethics. They believe that wrong procedures, diagnosis and treatments are factors of the malpractice. However, the participants adopt more consequentialism philosophy, which emphasize on effect on patients and lack of consideration what the doctors has done base on medical standards. More over, participants' explanations on medical malpractice are expression of dissatisfaction of medical services. The dissatisfaction is as a result of low of quality of information and attitude of doctors and other staffs in providing the services. Threfore, to improve public opinion on medical service and prevent medical malpractice allegation, doctors and other staffs have to obey professional standards and ethics, providing adequate information and good communication.

Key word: Medical malpractice, ethics, and public opinion. 


\section{Pendahuluan}

Dalam menjalankan profesinya, dokter harus berpedoman pada standar dan etika profesi. Etika kedokteran tersebut merupakan salah satu aplikasi dari filosofi etika. Oleh karena itu, teori-teori fislosofi etika menjadi landasan berpijak dari etika kedokteran, yaitu consequantialism (konsekuentialisme), deontologism (deontologisme) dan virtues of ethics (virtue etik). ${ }^{(1-4)}$

Konsekuentialis menilai baik buruk suatu perbuatan berdasarkan akibat dari perbuatan itu, bukan berdasarakan proses atau prosedur tindakan yang dilakukan. Berdasarkan sudut pandang konsekuantialis, suatu tindakan dikatakan salah jika efek yang ditimbulkannya adalah buruk. Sebaliknya, deontologis melihat baik buruknya suatu perbuatan, berdasarkan prosedur atau proses perbuatan tersebut. Dalam menilai benar atau salah suatu tindakan medis, deontologis berpijak pada standar profesi baku dari pada kondisi pasien akibat tindakan tersebut. Sedangkan virtuis menilai bahwa baik buruknya suatu tindakan dinilai berda-sarkan nurani atau niat dari sipelaku. Dalam hal ini, meskipun sulit dinilai, virtuis akan menilai suaru tindakan tersebut adalah salah jika niat dan tujuan sipelaku melakukannya adalah untuk kejahatan, meskipun yang ia lakukan sesuai dengan prosedur yang benar dan akhirnya tidak menimbulkan dampak negatif. $^{(1-4)}$ Landasan filosofis ini perlu dimengerti untuk menilai dan menganalisa pandangan masyarakat nantinya terhadap tindakan medis. Tambahan lagi, karena dalam prakteknya, landasan filosofis tersebut selau terkait satu sama lain dalam menilai suatu tindakan medis yang diterapkan kasus-perkasus ${ }^{(5)}$ atau bahkan sesuai norma dan hukum dimana kasus itu terjadi. ${ }^{(6)}$

Etika kedokteran dan kode etik profesi medis didasarkan atas prinsip- prinsip beneficence/non-maleficence

(memberikan manfaat/dan tidak memperburuk keadaan), respect for the autonomy (menghormati hak-hak pasien), justice (keadilan) and personal integrity (integritas pribadi tenaga medis). ${ }^{(6,7)}$ Perilaku yang bertentangan dengan prinsip-prinsip tersebutlah yang merupakan suatu malpraktek kedokteran. ${ }^{(6,7)}$

Di Indonesia, masyarakat mulai mengkritisi dan memberikan perhatian serius terhada prilaku dan tindakan profesional tenaga kesehatan. Banyak masyarakat meningkat kesadarannya akan hak-hak nya sebagai pasien saat mendapatkan pelayanan kesehatan. Khususnya sejak dikeluarkannya Undang-Undang No. 29 tahun 2004 tentang Praktek Kedokteran. ${ }^{(8)}$ Dengan merujuk pada UU tersebut, masyarakat makin sadar bahwa dokter dapat dituntut ke pengadilan bila dicurigai melakukan tindakan yang melanggar etika atau hukum. ${ }^{(9)}$ Tentunya, bila kesadaran akan hak dan tuntutan yang berlebihan tersebut bila tidak diiringi dengan pemahaman yang cukup tentang sisitim dan kondisi pelayanan kesehatan, maka ketidakpuasan akan pelayanan kesehatan dengan mudah memberikan tuduhan malpraktek.

Penelitian ini dilakukan untuk menilai bagaimana opini atau pandangan masyarakat tentang malpraktek kedokteran, yang dibandingkan atau dianalisis dengan prinsip-prinsip etika kedokteran.

\section{Metode}

Penelitian ini dilakukan pada Bulan November 2009 - Oktober 2010. Metode pengumpulan data pada penelitian ini adalah survei online, dengan fasilitas eSurveysPro dan menggunakan kuisioner sebagai instrumen pengumpulan data. Penelitian ini bersifat deskriptif dan kualitatif, yang 
mana sebahagian data-data yang dikumpulkan bersifat kualitatif, dengan menggunakan pertanyaan terbuka sehingga responden bisa mengemukakan pandapatnya secara bebas dan terbuka terhadap isu yang ditanyakan, dan tidak dibatasi pada isian atau skala teretentu.

Responden penelitian didapatkan dengan menggunakan sampling non-probabilitas convenience sampling, yakni kesediaan responden secara sukarela untuk berpartisipasi pada penelitian ini. Responden diundang untuk berpartisipasi pada penelitian ini melalui email langsung, mailing list dan atau jejaring sosial facebook.

Alasan menggunakan metode survei online dan metode sampling non-probabilitas convenience sampling adalah untuk mendapatkan cakupan yang lebih luas diseluruh Indonesia. Selain itu, karena sifat data yang diharapkan adalah opnini atau pendapat terbuka, sehingga reponden yang mau berpartisipsi pada penelitian ini adalah mereka mau memberikan pendapat mereka tentang isu yang ditanyakan. Pertimbangan etika suatu penelitian juga menjadi alasan dipilihnya metode ini, karena untuk memberikan respon pada suatu penelitian sosio-medis, seharusnya reponden memberikan persetujuan dan tanpa paksaan. Dengan menggunakan metode ini, syarat etika penelitian terpenuhi.

Sebelum dilakukan pengolahan data, respon yang akan diolah harus memenuhi syarat untuk dilakukan pengolahan data, yaitu pengisian data lengkap dan tidak terjadi pengisian ganda (yang ditandai dengan identitas responden dan IP address komputer sama). Selain itu, untuk menghindari bias opni masyarakat, responden yang berprofesi sebagai dokter juga dieksklusi dari pengolahan data.

Selanjutnya data-data kuantitatif dianalisa secara deskriptif, sedangkan data-data kualitatif dilakukan analisa tematik. Data-data kuat pendukuang juga ditampilkan dalam bentuk narasi. Data-data dianalisa menggunakan pendekatan prinsip-prinsip etika kedokteran.

\section{Hasil}

Didapatkan 146 responden yang memenuhi syarat untuk dilakukan pengolahan data pada penelitian ini. Responden penelitian ini tersebar hampir pada semua wilayah Indonesia, responden ada yang berada di Jakarta, kota-kota di Pulau Jawa, Sumatera, Kalimantan, Sulawesi, Bali dan Nusa Tenggara, Kepulaan Maluku dan Papua. dan terdapat juga berada di luar ngeri. 
Tabel 1. Karakteristik Responden

\begin{tabular}{|c|c|c|c|}
\hline \multicolumn{2}{|r|}{ Variabel } & \multicolumn{2}{|c|}{ Jumlah (n=146) } \\
\hline & & $\mathbf{f}$ & $\%$ \\
\hline \multirow{6}{*}{ Umur } & $<25$ & 0 & $0,00 \%$ \\
\hline & $25-30$ & 32 & $21,92 \%$ \\
\hline & $>30-35$ & 51 & $34,93 \%$ \\
\hline & $>35-40$ & 38 & $26,03 \%$ \\
\hline & $>40-45$ & 16 & $10,96 \%$ \\
\hline & $>45$ & 9 & $6,16 \%$ \\
\hline \multirow[t]{2}{*}{ Jenis Kelamin } & Laki-Laki & 83 & $56,85 \%$ \\
\hline & Perempuan & 63 & $43,15 \%$ \\
\hline \multirow[t]{9}{*}{ Profesi } & Dosen & 91 & $62,32 \%$ \\
\hline & PNS (Non Guru/ Dosen) & 30 & $20,54 \%$ \\
\hline & Guru & 5 & $3,43 \%$ \\
\hline & Pegawai BUMN & 5 & $3,43 \%$ \\
\hline & Pegawai Perusahaan Swasta & 5 & $3,43 \%$ \\
\hline & Praktisi: Hukum atau Akuntan & 3 & $2,05 \%$ \\
\hline & Pegawai/ Aktifis LSM & 2 & $1,37 \%$ \\
\hline & Swasta Mandiri/ Enterprenuer & 1 & $0,68 \%$ \\
\hline & Lain-Lain & 4 & $2,74 \%$ \\
\hline
\end{tabular}

Responden berusia dari 25 hingga di- apa yang dimaksud dengan malpraktek atas 45 tahun, dengan yang terbanyak kedokteran. Dari 138 responden terberkisar >30-35 tahun (34,93\%). sebut, 84,05\% mengemukakan bahwa Distribusi jender responden terdiri dari mereka mendapat pengetahuan tentang $56,85 \%$ laki-laki dan $43,15 \%$ perem- malpraktek dari media massa, seperti puan. Sedangkan profesi responden yang dapat dilihat pada tabel 2 . terbanyak adalah dosen $(62,32 \%)$ dan Berdasarkan informasi yang didapatnya PNS Non-Guru/Dosen (20,54\%), di media massa tersebut, umumnya seperti yang dapat dilihat pada tabel $1 . \quad(81,16 \%)$ responden berpendapat bahwa

Dari total 146 responden ter- malpraktek cukup banyak terjadi.

sebut, $138(94,5 \%)$ merasa tahu tentang 
Tabel 2. Sumber Informasi tentang Malpraktek Kedokteran

\begin{tabular}{lcc}
\hline \multicolumn{1}{c}{ Sumber Informasi } & \multicolumn{2}{c}{ Jumlah } \\
\cline { 2 - 3 } & f & $\mathbf{\%}$ \\
\hline Media Massa & 116 & $84,06 \%$ \\
Pelajaran Sekolah/ Perkuliahan & 10 & $7,25 \%$ \\
Orang Lain (Teman, saudara dll) & 6 & $4,35 \%$ \\
Bacaan lainnya (Bukan media massa dan bukan bagian pelajaran & 5 & $3,62 \%$ \\
sekolah) & & \\
Lainnya & 1 & $0,72 \%$ \\
\hline Jumlah & $\mathbf{1 3 8}$ & $\mathbf{1 0 0} \%$ \\
\hline
\end{tabular}

Secara umum responden berpendapat bahwa malpraktek kedokteran merupakan kesalahan yang dilakukan oleh dokter sehingga berakibat buruk bagi pasien. Sebagaimana halnya responden mengungkapkan, bahwa malpraktek kedokteran adalah:

"Adanya upaya dari tenaga medis yang mengadakan kegiatan praktek kedokteran yang tidak sesuai dengan ketentuan-ketentuan yang diatur didalam etika kedokteran,

Tabel 3. Opini Responden tentang Malpraktek

\begin{tabular}{|c|c|c|c|}
\hline \multicolumn{2}{|r|}{ Tema } & \multicolumn{2}{|c|}{ Jumlah (n=138) } \\
\hline & & $\mathbf{f}$ & $\%$ \\
\hline \multirow{5}{*}{$\begin{array}{l}\text { Dilihat dari Aspek } \\
\text { Pasien }\end{array}$} & Resiko buruk pasien, kecacatan atau kematian & 47 & $34,06 \%$ \\
\hline & Tidak menghargai hak-hak pasien & 3 & $2,17 \%$ \\
\hline & Penanganan tidak dengan persetujuan & 2 & $1,45 \%$ \\
\hline & $\begin{array}{l}\text { Tidak mendapatkan penjelasan tentang alternatif } \\
\text { pengobatan }\end{array}$ & 1 & $0,72 \%$ \\
\hline & $\begin{array}{l}\text { Tidak mendapat penjelasan tentang resiko } \\
\text { pengobatan/ tindakan }\end{array}$ & 1 & $0,72 \%$ \\
\hline \multirow{5}{*}{$\begin{array}{c}\text { Dilihat dari Aspek } \\
\text { Dokter/ Tenaga } \\
\text { Medis }\end{array}$} & Tidak sesuai ketentuan etika kedokteran & 22 & $15,95 \%$ \\
\hline & $\begin{array}{l}\text { Penanganan diluar atau tidak sesuai bidang } \\
\text { keahlian }\end{array}$ & 16 & $11,59 \%$ \\
\hline & $\begin{array}{l}\text { Kurang teliti dan hati-hati atau kelalaian } \\
\text { (careless) }\end{array}$ & 14 & $10,14 \%$ \\
\hline & Mengharapkan keuntungan semata atau finansial & 9 & $6,52 \%$ \\
\hline & $\begin{array}{l}\text { Tindakan ilegal (melawan hukum)/ } \\
\text { penyalahgunaan profesi }\end{array}$ & 5 & $3,62 \%$ \\
\hline Dilihat dari Proses & Kesalahan pengobatan atau penatalaksanaan & 34 & $22,63 \%$ \\
\hline
\end{tabular}

termasuk demi untuk memperoleh uang semata tanpa memikirkan resiko dan akibat yang terburuk bagi pasien" (R1).

Beberapa aspek tematik yang sering diungkapkan oleh responden yang disebut sebagai malpraktek adalah mengakibatkan kondisi pasien bertambah buruk, kecacatan atau fatal $(34,06 \%)$, seperti terlihat pada tabel 3 . 
Tindakan

\begin{tabular}{lrr} 
Kesalahan prosedur atau tidak sesuai SOP & 31 & $22,46 \%$ \\
\hline Kesalahan pemeriksaan atau diagnosis & 23 & $16,67 \%$ \\
\hline Tindakan coba-coba & 3 & $2,17 \%$ \\
\hline Kesalahan administratif & 1 & $0.72 \%$ \\
\hline
\end{tabular}

Responden juga menilai bahwa malpraktek kedokteran ada unsur kesalahan prosedur dalam pengobatan $(22,63 \%)$, tidak sesuai SOP $(22,46 \%)$ ataupun keslahan dalam diagnosis dan pemeriksaan $(16,67 \%)$. Sebagaimana beberapa responden menerangkan:

"Kesalahan yg dilakukan oleh tenaga paramedis, baik dokter atau perawat dalam menangani pasien, misalnya kesalahan pemberian suntikan dan dosis obat" (R78).

"Salah diagnosa dan salah ambil tindakan karena kecerobohan dokter/perawat" (R126).

Akan tetapi responden menitik beratkan kepada kondisi akhir pasien tanpa penjelasan riwayat dan perjalanan penyakitnya. Responden menilai apa yang dipahaminya sebagai malpraktek kedokteran berdasarkan akbibat yang dialami oleh pasien, tanpa melihat tindakan yang telah dilakukan dokter. Bahkan beberapa responden menegaskan, bahwa malpraktek adalah:

"Kesalahan dalam penanganan pasien yang sakit sehingga pasien semakin parah atau meninggal dunia. Kesalahan ini tentunya tidak disengaja kalau disengaja bukan malpraktek [namanya], tapi penganiayaan." (R3).

"Tindakan dokter yang semula dimaksudkan untuk menyembuhkan suatu penyakit, tetapi ternyata mengakibatkan penyakit tersebut tambah parah atau timbul penyakit lain" (R66).

"Keadaan dimana penyakit yang dialami seorang pasien menjadi semakin parah atau bahkan pasien tsb meninggal akibat kesalahan pihak rumah sakit atau dokter dalam memberikan penanganan atau diagnosa terhadap penyakit tersebut" (R136).

Meskipun responden menilai bahwa malpraktek kedokteran ada unsur kesalahan prosedur atau pengobatan, tetapi selalu dititik beratkan adalah kondisi pasien yang menjadi lebih buruk. Sebagaimana yang lainnya mengungkapkan:

"Kesalahan tindakan ataupun prosedur yang dilakukan dokter / tim dokter/para medis/rumah sakit terhadap pasien, yang merugikan pasien yang sering berdampak fatal seperti cacat permanen pada pasien atau malah meninggal dunia" (R18).

"Kesalahan prosedur dan atau tindakan medis yang dilakukan oleh seorang dokter terhadap pasiennya yang berefek buruk terhadap pasiennya" (R133).

Berdasarkan pemahaman responden apa yang dimaksudnya dengan malpraktek kedokteran, sebanyak 33 responden $(23,91 \%)$ mengaku pernah menjadi pihak korban dari mlapraktek kedokteran, baik yang dialami sendiri ataupun yang dialami keluarganya. Bentuk pengalaman terbanyak yang dianggap sebagai malpraktek oleh responden secara tematik adalah kondisi pasien menjadi lebih buruk setelah pengobatan $(21,21 \%)$, kesalahan diagnosis $(15,15 \%)$, dan kesalahan pemberian obat $(15,15 \%)$. Kasus-kasus lain, meskipun tidak banyak dilaporkan responden juga harus menjadi perhatian 
misalnya kelengkapan alat atau bahan medis untuk melakukan tindakan, tindakan tanpa persetujuan dan bahan atau alat kedokteran yang tertinggal setelah tindakan. Selengkapnya dapat dilihat pada tabel 4 .

Sebahagian besar pengalaman yang dimaksudnya dengan malpraktek lebih menitik beratkan pada rasa tidak puas akibat pelayanan dan kondisi memburuk setelah dilakukan pengobatan atau penatalaksanaan. Tidak jarang ungkapan responden tersebut jelas terlihat ketidakmengertiannya tentang penyakit yang diderita dan pelayanan yang dilakukan. Sehingga ungkapan ketidakpuasan tersebut, mengatakan kasus yang dialaminya merupakan malpraktek. Misalnya:

"Mertua saya sakit komplikasi Jantung dan Diabetes. Dokter selalu memberi obat yang rekasi obatnya hanya menghilangkan rasa sakit dan pemberian obat yang membuat ketergantungan. Akibatnya sudah membuat oragan tubuh lain diserang penyakit yaitu ginjal" (RP2).

"Anggota keluarga yang kena Kanker Payudara yang harus menjalani kemoterapi setelah operasi disalah satu RS di kota P. Pada Kemoterapi pertama, langsung dilakukan oleh perawat yang didampingi oleh dokter bedah tersebut tapi pada saat kemo yang kedua tidak didampingi oleh dokter bedah tersebut, maka terjadinya kerusakan jaringan sel di lengan tempat penyuntikan kemo tersebut sehingga kulit dan daging di lengan tersebut hangus seperti kebakar, setelah komplain ke dokter tersebut hanya diberi obat dan tidak ada pertanggungan jawaban dokter tersebut begitujuga RS tempat melakukan kemo. Pada kemo yang ke tiga, juga di dampingi oleh dokter tersebut dan terjadi juga seperti yang ke dua yang sampai akhirnya lengan tersebut lama kelamaan dagingnya mulai habis dan mengeluarkan bau yang tidak sedap" (RP7).

"Ayah saya terkena tumor usus besar sehingga harus dilakukan operasi untuk memotong tumor yang sepanjang $10 \mathrm{~cm}$ dari usus besar hingga anus. Operasi berjalan lancar dan dilanjutkan kemoterapi, namun kemudian urat saraf yang berhubungan dengan testis mungkin terpotong, kenyataannya ayah saya kemudian tidak dapat ereksi dan tidak dapat berhubungan badan, hal ini akhirnya mengakibatkan ayah saya patah semangat, dan kini ayah saya menderita strooke" (RP8).

Tabel 4. Bentuk-Bentuk Kasus Mapraktek Menurut Pengalaman Responden

\begin{tabular}{llr}
\hline \multicolumn{1}{c}{ Kasus } & \multicolumn{2}{c}{ Jumlah (n=33) } \\
\cline { 2 - 3 } & $\mathbf{f}$ & \% \\
\hline Kondisi pasien menjadi lebih buruk setelah pengobatan & 7 & $21,21 \%$ \\
Kesalahan diagnosis & 5 & $15,15 \%$ \\
Salah pemberian obat & 5 & $15,15 \%$ \\
Pananganan tidak sesuai keahlian & 3 & $9,09 \%$ \\
Efek samping berat tindakan infasif/ operasi & 2 & $6,06 \%$ \\
Kondisi fatal atau kematian setelah tindakan/ pengobatan & 2 & $6,06 \%$
\end{tabular}




\begin{tabular}{lll}
$\begin{array}{l}\text { Dokter tidak membrikan atensi yang cukup (kurang cermat, } \\
\text { tidak hati-hati atau tidak teliti). }\end{array}$ & 2 & $6,06 \%$ \\
Efek samping obat yang sangat jelek & 2 & $6.06 \%$ \\
Informasi yang diberikan dokter mempersulit keadaan & 2 & $6,06 \%$ \\
Terlambat penanganan & 1 & $3,03 \%$ \\
Dirawat tanpa persetujuan & 1 & $3,03 \%$ \\
Peralatan atau obat yang dibutuhkan pasien tidak siap/ tidak & 1 & $3,03 \%$ \\
tersedia & & \\
Bahan/ alat tertinggal setelah operasi/ tindakan & 1 & $3,03 \%$ \\
Dokter kurang cakap, kurang ilmu, seperti tidak tahu & 1 & $3,03 \%$ \\
Penatalaksanaan tidak tuntas & 1 & $3,03 \%$ \\
Pemeriksaan tidak tuntas & 1 & $3,03 \%$ \\
\hline
\end{tabular}

Penjelasan yang tidak baik atau tidak dipahami pasien, bila muncul kondisi yang tidak diinginkan juga bisa menimbulkan tuduhan negatif atau malah dianggap sebagai malpraktek. Misalnya, sebagaimana responden mengungkapkan:

"Pada saat itu anak saya yang kalau tidak salah baru berumur kurang dari setahun mengeluarkan seperti 'usus' setelah mencret, seperti benjolan didubur karena panik dari duburnya keluar sesuatu itu, saya bawa ke UGD..eh...langsung diinfus dan dirawat inap. Kebetulan hari raya, dokter ga ada...dua hari dibolehin pulang, para dokter ga bisa jelasin anak saya kenapa..katanya prolap ususlah, dan lainnya ngomong berbelit-belit tak bisa dimengerti. trus disuruh rawat jalan..ke dokter anak..dioper ke dokter bedah..ga jelas hubungannya...karenanya saya hentikan, karena sepertinya prosedurnya ga jelas dan dokterdokter ga tau atau pura-pura ngga tau apa sebab dan bagaimana penanggulanginya..yang jelas, semua harus bayar mahal..." (RP30).

"Anak saya yang saat itu Demam berdarah pada usia 1 tahun disarankan untuk tinggal, langsung membuka infus tanpa konsultasi terlebih dahulu, menakut-nakuti kami sebaga orang tua. Yang mana menurut pendapat saya lebih baik dirawat di rumah dimana dia akan merasa aman dan cepat sembuh, dibandingkan di suasana baru yang akan menambah stress anak dan memperlambat kesembuhan" (RP25).

\section{Diskusi}

Secara umum apa yang dipahami masyarakat sebagai malpraktek kedokteran sesuai dengan pandangan ilmu etika kedokteran, yaitu perilaku yang bertentangan dengan prinsip kemanfaatan/tidak memperburuk keadaan, intergritas, menghormati hak-hak pasien, dan keadilan. Secara teoritis, responden menilai bahwa malpraktek kedok-teran ada unsur kesalahan prosedur dalam pengobatan $(22,63 \%)$, tidak sesuai SOP $(22,46 \%)$ ataupun keslahan dalam diagnosis dan pemeriksaan $(16,67 \%)$. Akan tetapi mereka lebih menitik beratkan kepada kondisi akhir pasien tanpa penjelasan riwayat dan perjalanan penyakitnya. Sebahagiannya menilai apa yang dipahaminya sebagai malpraktek kedokteran berdasarkan akibat yang dialami oleh pasien, tanpa melihat 
tindakan yang telah dilakukan dokter. banyak merupakan ungkapan Meskipun unsur kesalahan prosedur ketidakpuasannya terhadap pelayanan atau pengobatan dipertimbangkan, kesehatan (RP2, 7 dan 8). Masyarakat tetapi selalu dititik beratkan adalah tidak mengerti tentang penyakit yang kondisi pasien yang menjadi lebih diderita serta prosedur tindakan atau buruk. pengobatan yang telah dilakukan. Dengan demikian, terlihat Terlihat, rangkaian kali-mat yang bahwa masyarakat lebih megadopsi diungkapkan responden antara satu nilai filosofis konsekuentialis yang fakta (kalimat) dengan fakta berikutnya, lebih menitik beratkan pada kondisi dalam pandangan ilmu kedokteran tidak akhir pasien dan kurang mempertimbangkan prosedur dan tindakan yang telah dilakukan oleh dokter berdasarkan nilai-nilai moral dan standar medis. Sebaliknya, dalam prinsip etika kedokteran, penilaian tindakan sebagai malpraktek kedok-teran dilakukan secara objektif. Kon-disi yang buruk setelah dilakukan pengobatan atau tindakan operatif tidaklah dapat disimpulkan akibat kesalahan medis. ${ }^{(10-}$

12) Kondisi yang memburuk setelah dilakukan piñata-laksanaan tersebut perlu dilihat apakah memang telah terjadi kesalahan prosedur penatalaksanaan tersebut yang tidak sesuai dengan standar medis untuk kasus tersebut, seperti obat yang tidak sesuai, dosis yang tidak sesuai, dan efek samping obat akibat tidak adekuatnya anamnesis pasien. ${ }^{(11)}$

Terdapat kasus-kasus yang menjadi perhatian dokter, rumah sakit, dan petugas kesehatan lainnya, seperti ketidaksiapan alat dan tidak adanya persetujuan sebelum dilaku-kannya penatalaksanaan. Hal ini tentu perlu dicermati, karena tidak hanya menimbulkan tuntutan malpraktek malah mencerminkan tidak bermutunya pelayanan yang diberikan. Padahal, khususnya per-setujuan pasien atau keluarga merupakan langkah sederhana yang dapat mengurangi berbagai tuntutan malpraktek. ${ }^{(13,14)}$

Akan tetapi, pandangan masyarakat tentang apa yang dimaksudnya dengan pengalaman malpraktek lebih nyambung. Hal ini tentu adalah akibat dari rendahnya kualitas komunikasi dan penjelesan yang diberikan dokter sebelum melakukan tindakan ter-sebut. Akibatnya, pasien mengira-ngira dan bahkan menuduh kondisi jelak yang muncul setelah itu adalah akibat tindakan tersebut. Pasien tentu tidak punya pengetahuan tentang perjalanan penyakit dan komplikasi penyakit primernya. Sehingga bila ini tidak dijelaskan pada pasien, dan komplikasi tersebut muncul semasa pengobatan, maka tentulah tidak tidak terlalu disalahkan bila pasien atau masyarakat menyalahkan dokter dan rumah sakit. Begitu juga misalnya, reaksi alergi obat yang menyebabkan bengkak lidah dan mulut bisa juga dituduh sebagai tindakan malpraktek akibat kelebihan obat (RP12). Pada-hal reaksi ini bia terjadi akibat reaksi alergi obat, meskipun pengobatan teah tepat dosis. Jika riwayat alergi obat telah ditanyakan dan telah membrikan obat yang tepat, kemudian masih muncul reaksi alergi, secara medis dokter telah melakukan sesuai standar. Jika hal ini tidak dilakukan, tentunya inilah kesalahan dokter tidak menggali riwayat alergi obat sebelum pemberian obat. Bukan seperti yang dituduhkan akibat kelebihan dosis.

Pada kasus anak diare dengan keluar benjolan (RP30), terlihat jelas bahwa pasien tidak mendapatkan penjelasan yang cukup terhadap prosedur penatalaksanaan yang 
dilakukan. Sangat mungkin dokter yang menanganinya menduka kasus ini suspek atau diagnosa klinis suatu prolapsus rektum, yang membutuh-kan pemeriksaan yang cermat dan konsultasi beberapa dokter ahli termasuk spesialis anak dan spesialis bedah. Jika hal ini terjadi tentu membutuhkan tindakan operatif. ${ }^{(15,16)}$ Akan tetapi, karena orang tua pasien tidak mendapatkan penjelasan yang cukup, ia merasa dipermainkan dan menuduh tindakan tersebut suatu malpraktek.

Begitu juga halnya dengan kasus demam berdarah (RP25). Penjelasan yang diberikan dokter dan perawat tidak memberikan pemaha-man yang cukup bagi orang tua pasien sehingga ia mengganggapnya malah menakutnakuti. Demam ber-darah pada anak, yang disertai gangguan sirkulasi atau telah terjadi syok berat (DBD derajat III dan IV) membutuhkan perawatan, peman-tauan serius dan pemberian cairan parenteral (infus). ${ }^{(17)}$ Orang tua pasien hanya mengirangira dengan mengatakan "Menurut pendapat saya" yang mengindikasikan dia tidak diberikan penjelasan yang cukup tentang kondisi penyakit anaknya.

Oleh karena itu untuk mencegah terjadinya tuduhan malpraktek, dokter harus memberikan informasi yang cukup dan dan dipa-hami oleh pasien tentang penyakitnya dan penatalaksanaan yang akan dilakukan, serta meminta persetujuan tertulis (informed consent) sebelum penatalaksanaan itu dilakukan. ${ }^{(13,14)}$ Semua tindakan yang dilakukan tersebut harus dicatat dengan rapi, ${ }^{(18-20)}$ terlebih lagi jika terjadi pada kasus-kasus yang beresiko tinggi untuk terjadinya tuntutan, seperti di unit gawat darurat. ${ }^{(21)}$ Komunikasi yang baik terhadap pasien bisa mengurangi ketidakpuasan pasien terhadap dokter. ${ }^{(13,22)}$
Ketidakpuasan pasien dan masyarakat terhadap pelayanan yang diberikan dokter dan rumah sakit selalu akan selalu ada. Beberapa kepustakaan menunjukkan bahwa selalu ada perbedaan ekspektasi pasien terhadap dokter dengan apa yang seharusnya dilakukan ber-dasarkan standar pelayanan medis. ${ }^{(23,24)}$ Terlebih lagi, tindakan medis membutuhkan saintifik sebe-lum berbagai tindakan invasif, tindakan diagnostik, medik, bedah dan berbagai pengobatan lainnya, ${ }^{(25)}$ yang sering kali tidak dipahami oleh masyarakat.

Pemahaman respondent tentang malpraktek tersebut umumnya berdasarkan pengetahuan yang didapatnya dari media massa. Bahkan mereka menilai malpraktek banyak terjadi, seperti apa yang sering dilaporkan di media massa. Dengan demikian terlihat bahwa media massa memegang peranan penting dalam membentuk opini masyarakat tentang pelayanan kesehatan dan isu-isu malpraktek. Padahal penggambaran isu di media tidak selalu mencerminkan realita yang sesungguhnya. ${ }^{(21)}$

Akan tetapi, pemberitaan dan kritisi di media dapat mendidik masyara-kat untuk meningkatkan kesadarannya tentang hak-hak dan tanggung jawabnya. Hal ini bisa terwujud jika kritisi tersebut dilakukan secara berimbang, karena hubungan profesional dokter-pasien adalah kontrak pelayanan medis yang kedua belah pihak harus menyadari akan hak dan tanggung jawabnya. ${ }^{(26)}$ Begitu juga halnya bagi dokter, keterlibatan media dalam mengkritisi pelayanan kesehatan dapat meningkatkan akuntabilitas pelayanan tersebut secara sosial dan mencegahnya dari kelalaiaan dan keteledoran (careless and negligence), serta dapat meningkatkan kesdaran mereka akan tanggung jawab profesional dan moral, kode etik, 
penegakan hukum, dan hak-hak
pasien.

\section{Kesimpulan}

Opini masyarakat tentang malpraktek kedokteran sesuai dengan pandangan ilmu etika kedokteran. Masyarakat juga memahami bahwa kesalahan prosedur, diagnosis dan penatalaksanaan merupakan aspek dalam terjadinya malpraktek. Namun masyarakat lebih menitik beratkan kepada akibat yang dialami oleh pasien, yang lebih megadopsi nilai filosofis konsekuentialis dan kurang mempertimbangkan tindakan yang telah dilakukan oleh dokter berdasarkan nilai-nilai moral dan standar medis.

Beberapa pengalaman masyarakat tentang malpraktek kedokteran terdapat kasus-kasus yang harus menjadi perhatian dokter, rumah sakit, dan petugas kesehatan lainnya, seperti ketidaksiapan alat dan tidak adanya persetujuan sebelum dilaku-kannya penatalaksanaan. Akan tetapi, lebih umum pandangan masyarakat tentang apa yang dimaksudnya dengan pengalaman malpraktek merupakan ungkapan ketidakpuasannya terhadap pelaya-nan yang didapatkan. Ketidakpuasan tersebut muncul akibat kurangnya komunikasi dan rendahnya kualitas informasi dari dokter atau petugas kesehatan. Oleh karena itu untuk mencegah berbagai tuduhan malpraktek, maka komunikasi yang baik dan pemberian informasi yang cukup mutlak dilakukan sebelum tindakan pemeriksaan dan pengobatan dilakukan.

\section{KEPUSTAKAAN}

1. Rogers WA, Braunack-Mayer AJ. Practical Ethics for General Practice, $2^{\text {nd }}$ edition. Oxford: Oxford University Press, 2009.
2. Häyry M. Utilitarianism and bioethics. In: Ashcroft RE, Dawson A, Draper H, McMilllan JR. Principles of Health Care Ethics. Sussex, England: Johnson Willey and Son, 2007. p. 57-64.

3. Mcnaughton DA, Rawling JP. Deontology. In: Ashcroft RE, Dawson A, Draper H, McMilllan JR. Principles of Health Care Ethics. Sussex, England: Johnson Willey and Son, 2007. p. 65-71.

4. Oakley J. Virtue theory. In: Ashcroft RE, Dawson A, Draper H, McMilllan JR. Principles of Health Care Ethics. Sussex, England: Johnson Willey and Son, 2007. p. 87-91.

5. Jonsen AR. Casuistical reasoning in medical ethics. In: Ashcroft RE, Dawson A, Draper H, McMilllan JR. Principles of Health Care Ethics. Sussex, England: Johnson Willey and Son, 2007. p. 51-56.

6. Sheehan M. Moral relativism. In: Ashcroft RE, Dawson A, Draper H, McMilllan JR. Principles of Health Care Ethics. Sussex, England: Johnson Willey and Son, 2007. p. 92-98.

7. Cullity G. Beneficence. In: Ashcroft RE, Dawson A, Draper H, McMilllan JR. Principles of Health Care Ethics. Sussex, England: Johnson Willey and Son, 2007. p. 19-26.

8. Pemerintah Republik of Indonesia. Undang-Undang Republik Indonesia Nomor 29 Tahun 2004 tentang Praktik Kedokteran. Jakarta: Pemerintah Republik Indonesia, 2004. 
9. Murphy AM. The role of Professional Organizations in Indonesia's Socio-political Transformation. NBR Analysis. New York: Columbia University, 2008.

10. Gidwani S, Zaidi, SMR. Birchen MD. Medical negligence in orthopedic surgery: areview of 130 consecutive medical negligence report. Journal of Bone and Joint Surgery 2009; 91B: 151-156.

11. Madea B, Mushoff F, Presuss J Medical negligegence in drug associated death. Forensic International, 2009. pp. 190: 67-73.

12. Varetto L, Cargallo C. Intraabdominal needle: medical malpractice? Forensic International 2009; 191: e11-e13.

13. Kraushar MF. Toward more effective risk prevention. Survey Ophthalmology 2009; 54(1): 150157.

14. Martinez JA, Lyons JM, O'Leary JP. Medical malpractice matters: informed consent. Journal of Surgical Education 2009; 66(3): 174-175.

15. Mellgren A, Pollack J, Schultz I. Rectal prolapse, rectal intussusception, and solitary rectal ulcer syndrome. In Bayless TM, Diehl, AM. Advanced Therapy in Gastrology and Liver Disease. $5^{\text {th }}$ Edition, Hamilton Canada: B.C. Decker Inc., 2005. p. 518-525.

16. Altomare DF, Pucciani F. Rectal Prolapse: Diagnosis and Clinical Management. $1^{\text {st }}$ Edition. New York: Springer, 2007.
17. Soedarmo SP. Infeksi virus Dengue. Dalam Soedarmo SP, Garna H, Hadinegoro SRS (Editor). Buku Ajar Ilmu Kesehatan Anak: Infeksi dan Penyakit Tropis. Edisi Pertama. Jakarta: Bagian IKA FK-UI dan IDAI, 2002. p. 176-208.

18. Reynard J, Marsh, H. Unusual and so unusual ways of ending up in court: how to avoid litigation. British Journal of Urology 2009; 104: 586-589.

19. Kane SM, White RA. Medical malpractice and sport medicine clinician. Clinical Orthopedic and related Research 2009; 467: 412419.

20. Fishbain PA, Lewis, JE, Gao J, Cole B. Rosemoff RS. Alleged medical abandonment in chronic opioid analgesics therapy. Pain Medicine 2009; 10(4): 272-279.

21. Wu CY, Lai HJ, Chen RC. Patient characteristic predict occurrence and outcome of complaints against physician: a study from a medical center Taiwan. Journal Form. Med Assc. 2009; 108(2): 126-134.

22. Robbenfolt JK. Apologies and medical error. Clinical Orthopedic and related Research 2009; 467: 376-382.

23. Lin PJ. Criminal judgments to medical malpractice in Taiwan. Legal Medicine 2009; 11: S376378.

24. Rahman MM, Rahman S, Begum N, Asaduzzaman AKM, Shahjahan M, Firoz A, Metul MS. Client expectation from doctors: Expectation - reality gap. 
Kathmandu University Medical Journal 2007; 5(4): 566-573.

25. Engel E, Livingston EH. Solving the medical malpractice crisis: use a clear and convincing evidence standard. Archive Surgical 2009; 145(3): 296-300.

26. Sacapulos M, Segal JJ. Limiting exposure ti medical malpractice claims and defamatory cyber posting via patient contract. Clinical Orthopedic and Related Research 2009; 467: 427-433.
27. Sloan F, Shade J. Is there empirical evidence for defensive medicine? A reassessment. Journal of Health Economic 2009; 28: 481-491.

28. Taborda JGU, Abdalla FE, Dohler C, Bins HDC. Legal control of the medical profession. Current Opinion Psychiatry 2009; 22: 492496. 